\title{
GST: A Step towards Strengthening Indian Economy
}

\author{
Dr. Gulshan Kumar ${ }^{1}$, Som Prakash ${ }^{2}$ \\ ${ }^{1}$ Associate Professor, Rajshree Institute of Management \& Technology, Bareilly. \\ ${ }^{2}$ Assistant Professor, Rajshree Institute of Management \& Technology, Bareilly. \\ gulshan_kumar547@rediffmail.com
}

\begin{abstract}
The idea of Goods \&Service Tax (GST) was contemplated in 2004 by the Task Force, named Kelkar Committee, on the implementation of Fiscal Responsibility and Budget Management Act, 2003 in India. This Committee was convinced that a dual GST system shall be able to tax all the goods and services in Indian Economy. It will be helpful to cover wider market of tax base system and also help to improve revenue collection through levying and collection of indirect tax. According to GST, every person is liable to pay tax on output and tax will be apply only on value added amount. GST consider the principle of "one nation, one tax and one market." GST exists in more than 160 countries of the world. It will help to improve the productivity in the country as well as benefited to the consumers because as maximum rate of GST is predetermined. It helps to avoid double taxation system, tax evasion etc. Government proposed State GST as well as Central GST. State GST includes sales tax/VAT which are collected by states and Central GST includes excise duty, custom duty, service tax etc which are imposed by Central Government. In GST, goods and services rates classified under different five categories of taxes: - 0 percent, 5 percent, 12percent, 18percent and 28 percent. The GST bill was implemented in India from $1^{\text {st }}$ April 2017. In this particular research paper we discuss about probable pros and cons of GST system in Indian context and positive and negative impact of GST on businesses and Indian Economy.
\end{abstract}

Keywords: GST, Tax, Impact of GST, Indian Economy.

\section{INTRODUCTION}

GST was introduced in France in 1954 and now more than 160 countries are following the GST system. The idea of GST was introduced in 2000 in India and Government appointed different committees and task force to study the impact of GST in Indian context. The effort to implement GST was floated in Union Budget 2006-2007 by the Finance Minister of India. Finally approval by Lok Sabha and Rajya Sabha, GST system was introduced from $1^{\text {st } J u l y ~ 2017 . ~ G S T ~ m o d e l ~ c o m p r i s i n g ~ " D u a l ~ G S T " ~ w h i c h ~ i n c l u d e ~ C e n t r a l ~ a n d ~ S t a t e ~ c h a r g i n g ~ G S T ~ s i m u l t a n e o u s l y ~}$ on the common base. The administrative responsibility lies with GST Council.

GST is an indirect tax that brings most of the taxes imposed on most goods and services, on manufacture, sale and consumption of goods and services, under a single domain at the national level. It is payable at the final stage of consumption. At each stage of sale or purchase in the supply chain, this tax is collected on value- added on goods and services through a tax credit mechanism. GST can help in reducing taxation and filing costs and expand business profitability, attract investment and improve tax compliance and increase tax revenue in the country.

Fiscal intervention will require a lot of efforts from the government to put in place major changes. Fiscal intervention could be taxes - personal, corporate and wealth in case of direct taxes. In case of indirect taxes, it may be excise, customs and sales tax. Implementation of GST in India would require a major effort to control to control the disparity among different taxes and other burden of taxes.

Economy of India is getting more globalised over the past two decades. Introduction of an Integrated Goods and Service Tax (GST) to replace the prevailing multiple tax structures of Centre and State taxes is very imperative 
GST: A Step towards Strengthening Indian Economy

in the changing economic environment. Moving towards GST is the biggest change in tax reforms in liberalized economy.

\section{OBJECTIVES OF THE STUdY}

The study is based on the following objectives:-

1. To study about the concept of GST.

2. To study the pros and cons of GST.

3. To study the positive and negative impact of GST on Indian economy.

\section{RESEARCH MeTHOdology}

The data for the study were gathered from the secondary sources such as journals, articles published online and offline on various newspapers and websites.

\section{LITERATURE REVIEW}

Garg, Girish (2014) studied "Basic Concepts and Features of Good and Service Tax in India" and concluded that GST will affect different sectors of the economy differently - where it will double the tax burden on food items (like cereals, grains, dairy products etc.) and thus is not preferable, it is essential for the construction, housing and FMCG industries for their growth and expansion.

Saravanan Venkadasalam (2014) has studied the consequence of GST on the economic growth of ASEAN States using Least Squares Dummy Variable Model (LSDVM). As we know that seven of the ten ASEAN nations have already been using the GST. He recommended that the household final consumption expenditure and government general consumption expenditure are positively considerably related to the GDP (Gross Domestic Product). But the outcome of GST differs in countries. Philippines and Thailand show major negative relationship with their national growth. On the other hand, Singapore shows a momentous positive relationship.

Shefali Dani (2016) studied "Impact of Goods and Service Tax (GST) on Indian Economy" and found out that GST will simplify the current indirect heterogeneous tax structure, remove inefficiencies, is applicable and successful in over 150 countries, but it may falter in India due to likely inflation and also its impact on certain industries like telecommunication.

Raj Kumar(2016) studied "Comparison between Goods and Services Tax and Current Taxation System and found out that if we compare different taxes and duties levied under present tax system and under GST, GST will simplify the processes, bring transparency, higher output, employment opportunities and economic growth.

Lourdunathan F and Xavier P (2017) studied "Implementation of goods and services tax (GST) in India: Prospectus and challenges" and observed that GST will make one tax, one nation, will provide relief to producers and consumers through input credit set-off, will result in resource and revenue gain at both Central and State levels.

\section{Pros of GST}

There are the following pros of GST:-

- GST introduced One-Country-One -Tax Regime

- GST divided all indirect taxes at the state and central level.

- GST widen the tax regime by covering goods and services as well as make it transparent.

- GST increased consumption by brought down the prices of goods and services.

American Research Journal of Business and Management Page 2 
GST: A Step towards Strengthening Indian Economy

- GST created business-friendly environment by increase tax-GDP ratio.

- GST reduced the cascading effect of taxes on the final price of the product.

- GST eliminated multiple taxes.

- GST reduced black money in the market, need for financial documentation increased.

- Higher threshold for registration.

- GST introduced composition schemes for small business.

- Online simple procedure under GST.

- Lesser compliances.

- Regulating the unorganised sector.

- Employment opportunities generation for youths as GST trained experts.

\section{Cons of GST}

There are some cons of GST are as follows:-

- GST made some services and goods expensive.

- All credits are online and some penalties applied. So it is threatening for some business men who were free from the taxes in the past.

- Maintenance of record is not easy for small businessman because it compiles many types of taxes.

- Learning of new tax system required would not be an easy tax for the small traders.

- Necessity of internet, laptops and computers required for small traders who lack such kind of facilities.

- Local dealers have to be paid GST at both level CGST and SGST level.

- Few industries negatively affected by the GST system like Real Estate etc.

- GST system stated heavy reduction in the collection of GST during some last years.

\section{POSITIVE IMPACT OF GST ON INDIAN ECONOMY}

There are following positive impacts of GST on Indian Economy:-

- Reduce the burden of tax on manufactures and producers through more production.

- Single tax system eliminates the different tax barriers.

- Government Revenue increased after the implementation of GST.

- Some sectors like Auto Commercial Vehicle, consumer goods, footwear, cigarettes, building material and logistics make grow due to reduction of tax on different items under GST.

\section{NEGATIVE IMPACT OF GST ON INDIAN ECONOMY}

There are following positive impacts of GST on Indian Economy:-

- Some sectors like Hotels, Restaurant and Branded Apparels go down due to increase in tax rates on different items under GST.

- GST tax rate varies from $0 \%, 5 \%, 12 \%, 18 \%$ and $28 \%$ which is limited for the whole taxation system earlier separate tax rate existed for different goods and services. 
- Growth in inflation might be effect due to GST.

- Increased value of offerings approach, an upload on for your monthly prices.

- Reorganization of the budgets to endure the additional services cost.

\section{CONCLUSION}

From the above description, we can say no doubt that GST is the biggest ever change in tax structure of India. GST is the most logical steps towards the comprehensive indirect tax reform in our country since independence. It is leviable on all supply of goods and provision of services as well combination thereof. All sectors of economy whether the industry, business including Government departments and service sector shall have to bear impact of GST. As a result, there is a fall in prices of some items like Auto Commercial Vehicle, Two wheelers, Small cars, Midsized cars and SUV, essential items, Footwear, Building Materials etc., but on the other hand, price of some other goods and services hiked after GST like Hotel room rental, Restaurants \& fine dining and Branded Apparels etc. Implementation of GST leads to gain in GDP, exports and growth of the economy.

\section{REFERENCES}

- Garg, Girish (2014), "Basic Concepts and Features of Good and Service Tax in India”, International Journal of Scientific Research and Management, volume 2, issue 2.

- Vasanthagopal, R. (2011). GST in India: A Big Leap in the Indirect Taxation System. International Journal of Trade, Economics and Finance, 2(2), 144.

- P, Lourdunathan F and Xavier. "A study on implementation of goods and services tax (GST) in India: Prospectus and Challenges." International Journal of Applied Research, 2017: 3(1): 626-629.

- Kumar, Raj. "Comparison between Goods and Services Tax and Current Taxation System A Brief Study." International Journal of Allied Practice, Research and Review III, no. IV (2016): 9-16.

- Dani S (2016) A Research Paper on an Impact of Goods and Service Tax (GST) on Indian Economy. Bus Eco J 7: 264. doi: 10.4172/2151-6219.1000264

- Venkadasalam, Saravanan. "Implementation of Goods and Service Tax (GST): An Analysis on ASEAN States using Least Squares Dummy Variable Model (LSDVM)." In International Conference on Economics, Education and Humanities (ICEEH'14), Bali (Indonesia), Pg, no. 7-9. 2014.

- Dr. S. Vasanthagopal (2011), "GST in India: A Big Leap in the Indirect Taxation System”, International Journal of Trade, Economics and Finance, Vol. 2, No. 2, April 2011.

- Jain, A. (2013). An Empirical Analysis on Goods and Service Tax in India: Possible Impacts, Implications and Policies. International Journal of Reviews, Surveys and Research, 2(1).

- Purohit, M. C., \& Purohit, V. K. Goods and Services Tax in India.

- Khurana A, Sharma A (2016) Goods and Services Tax in India-A Positive reform for Indirect Tax System. International Journal of Advanced Research.

- Nitin K (2014) Goods and Services Tax in India: A way forward. Global Journal of Multi-disciplinary Studies

- Shaik, S., Sameera, S. A., \& Firoz, M. S. C. (2015). Does goods and services tax (GST) leads to Indian economic development. IOSR Journal of Business and Management, 17(12), 01-05. 
GST: A Step towards Strengthening Indian Economy

- Vikas, Kumar (2016). GST: Positive and Negative Effects on Common Man in India. Journal of Commerce and Trade, 11(2), 113-117.

- Suresh, P., Sivakumar, T. (2016). Overview of GST in India. KAAVInternational Journal of Economics, Commerce and Business Management, 3(4), 290-304.

Citation: Dr. Gulshan Kumar, Som Prakash. "GST: A Step towards Strengthening Indian Economy". American Research Journal of Business and Management. 2020; 6(1): 1-5.

Copyright (c) 2020 Dr. Gulshan Kumar, Som Prakash. This is an open access article distributed under the Creative Commons Attribution License, which permits unrestricted use, distribution, and reproduction in any medium, provided the original work is properly cited. 